\title{
Idea stosowania progów zwalniających i ich wpływ na ludzi i środowisko
}

JEL: R41 DOI: 10.24136/atest.2019.179

Data zgłoszenia: 05.04.2019 Data akceptacji: 26.06.2019

W artykule opisana została definicja oraz wymienione zostały rodzaje progu zwalniającego jak również jego idea a także cel zastosowania. Pozytywne jak i negatywne skutki stosowania progów zwalniających. Poruszony został problem drgań i hałasu, które sa przyczyną stosowania progów oraz inne niż progi metody i rozwiązania alternatywne ograniczenia ruchu drogowego.

\section{Wstęp}

Postęp cywilizacyjny jaki obserwujemy na przełomie ostatniego stulecia jest ogromny - zarówno motoryzacyjny, jak i przemysłowy, a także drogowy. Sięgnijmy początków 1918 roku, gdzie władze odrodzonej Polski stanęły przed problemem odbudowy, rozbudowy, a przede wszystkim dostosowania potrzeb komunikacyjnych. $\mathrm{Na}$ obrzeżach byłych zaborów znajdowały się liczne bezdroża ale również w przypadku kolei brakowało licznych połączeń pomiędzy kluczowymi ośrodkami kraju. Określono, że do odpowiedniego i jednolitego stworzenia systemu połączeń sieci komunikacyjnych należy zbudować około 75000 km nowych dróg. Do roku 1938 wybudowano w Polsce $17600 \mathrm{~km}$ nowych dróg, nowe drogi w większości uzupełniały sieć lokalną natomiast autostrady były w fazie wstępnego projektowania. Po II wojnie światowej jednak większość tych dróg należało odbudować bądź zmodernizować. Do roku 2018 infrastruktura drogowa bardzo się rozwinęła i rozwija się dalej. Wraz z dużym rozwojem sieci dróg komunikacyjnych rozwinęła się również motoryzacja, a wraz z nią zwiększone ryzyko zagrożenia dla człowieka i środowiska. Szczególnie negatywny wpływ mają drogi szybkiego ruchu, które zajmuja duże tereny, jak również ruch na nich jest bardzo wzmożony, a przez to odczuwalny dla ludzi i otaczającego środowiska. Na drogach gminnych i powiatowych, ze względów bezpieczeństwa przede wszystkim dla pieszych, zastosowano elementy uspokajania ruchu drogowego takie jak:

- progi zwalniajace,

- zwężenia do jednego pasa ruchu,

- ronda,

- półprzegrody,

- fale uspokajajace,

- paski zwalniajace,

- wysepki z azylem dla pieszych.

Zastosowanie ww. środków przyczyniło się do:

- zmniejszenia liczby wypadków z udziałem pieszych

- zmniejszenia prędkości ruchu tranzytowego

- zmniejszenia liczby wykonywania niebezpiecznych manewrów na drodze

- uporządkowania ruchu zarówno drogowego, jak i rowerowego

Należy tutaj wspomnieć m.in. badania naukowców z Politechniki Krakowskiej, a także audyty przeprowadzane dla Zarządu dróg
Miasta Krakowa, z których wynika, że dzięki zwężeniu pasa jezdni przed przejściem dla pieszych szanse pieszego na płynne przejście przez ulicę zwiększyły się z około $65 \%$ do prawie $90 \%$.Wcześniej kierowcy przejeżdżali przez przejście z prędkościami bliższymi 70 $\mathrm{km} / \mathrm{h}$, po zastosowaniu ww. elementu uspokojenia ruchu prędkość spadła do około $50 \mathrm{~km} / \mathrm{h}$.

Najbardziej popularne elementy uspokajania ruchu to progi zwalniające, które są powszechnie stosowane na drogach lokalnych, ale ich częste stosowanie niekoniecznie dobrze wpływa na ludzi i otaczające nas środowisko.

Próg zwalniajacy - jest to środek służący do uspokajania ruchu, przeważnie w postaci poprzecznej wypukłości na jezdni. Jego celem jest ograniczanie prędkości pojazdów poruszających się po drodze na której został zainstalowany. Przejazd przez próg zwalniający

z prędkością powyżej dopuszczalnej skutkuje podbiciem kół samochodu oraz wyczuwalnym dyskomfortem zarówno dla kierowcy, jak i pasażerów, przez co (w założeniu) zmusza do przejazdu przez niego z ograniczoną prędkością, zazwyczaj $20 \mathrm{lub} 30 \mathrm{~km} / \mathrm{h}$. Materiał służący do wykonania progów to zazwyczaj guma, asfalt bąź́ kostka betonowa.

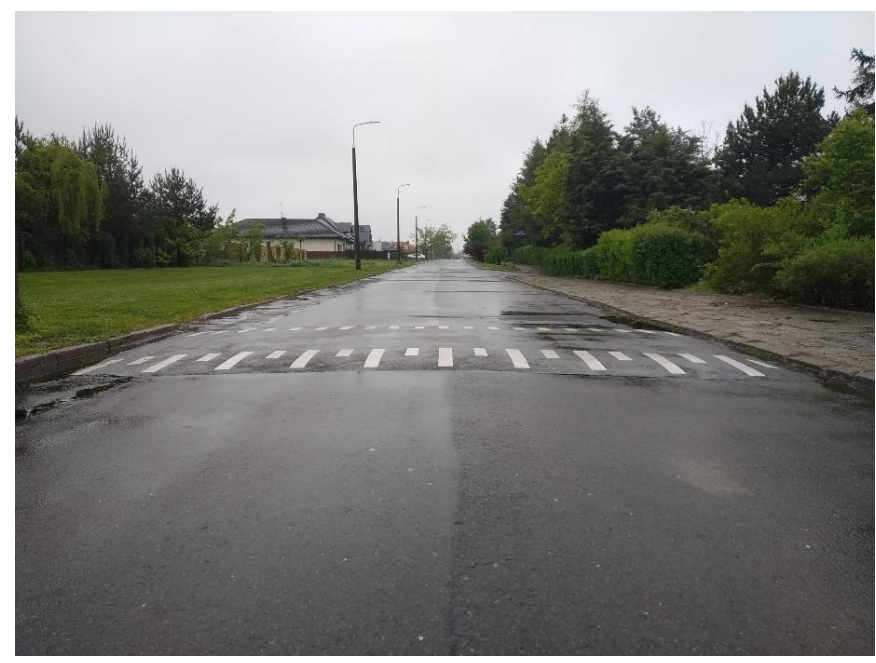

Rys. 1. Próg zwalniający

źródło: [własne]

Konstrukcja progów zwalniających jest nieustannie rozwijana. Cel nakierowany jest przede wszystkim na ograniczanie niedogodności związanych z przejazdem przez próg pojazdów poruszających się po drodze $z$ dozwoloną prędkością, oraz zminimalizowaniem niszczenia pasa drogi wokół progu.

Poniżej przedstawiono kilka innowacyjnych rozwiązań:

- Próg z zawiasem w środku i zamontowanym amortyzatorem o tak dobranych parametrach, by próg spłaszczał się przy powolnym przejeździe, a pozostawał wypukły przy przejeździe z większą prędkością. 

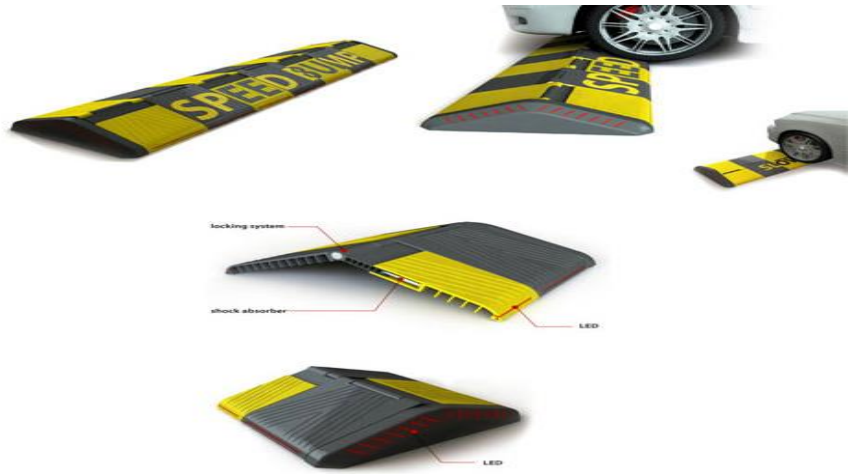

Rys. 2. Próg z zawiasem w środku i amortyzatorem źródło: [8]

- Próg ma postać rękawa wypełnionego ciecza, która rozpływa się przy powolnym najeździe pojazdu, a stawia opór przy najeździe z dużą prędkością.

- Próg ma nawierzchnię elastyczna, która zapada się przy przejeździe ciężkiego pojazdu np. autobusu, a pozostaje na miejscu podczas przejazdu samochodu osobowego. Dzięki temu ogranicza się wibracje, które powstają podczas przejazdu pojazdów ciężkich przez progi zwalniające i zwiększa się komfort pasażerów komunikacji zbiorowej

Do powszechnie znanych rodzajów progów zwalniających zaliczamy następujace:

- Pinezka - to próg stosowany na skrzyżowaniach, ma postać okragłej wypukłości na środku skrzyżowania o średnicy tak dobranej by przejazd przez skrzyżowanie odbywał się częściowo przez próg. Skrzyżowanie z progiem typu pinezka jest bardzo podobne do mini ronda, lecz różni się od niego tym, że nie obowiązuje na nim ruch okrężny(rys. 3)

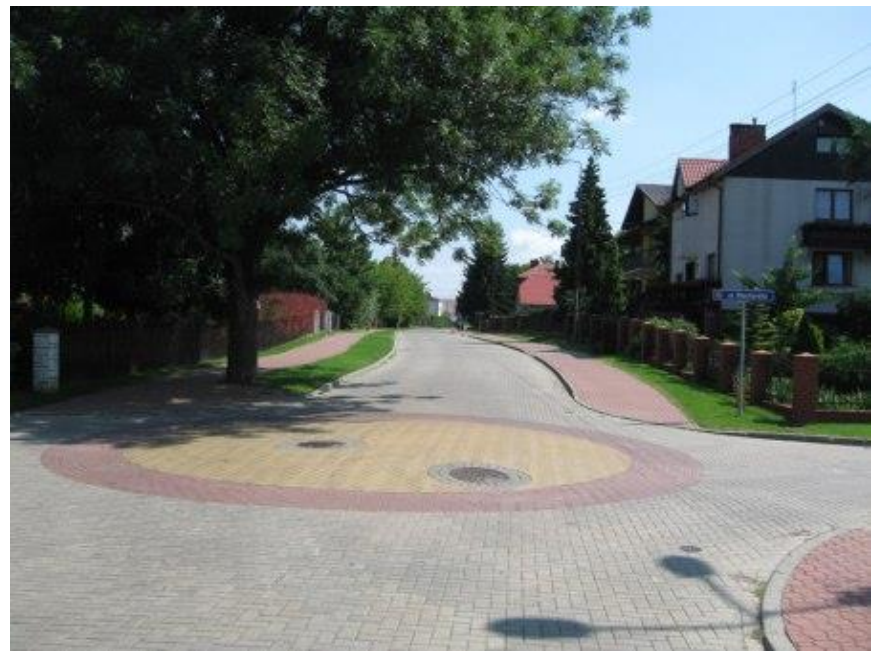

Rys. 3. Próg zwalniający typu pinezka

źródło: [11]

- Poduszka - to także próg stosowany na skrzyżowaniach. Od progu typu Pinezka różni się ksztaltem. Próg typu poduszka ma kształt prostokątny. W przeciwieństwie do skrzyżowania $z$ wyniesiona powierzchnia nie obejmuje całej tarczy skrzyżowania lecz jedynie jej środkowy fragment (rys. 4)

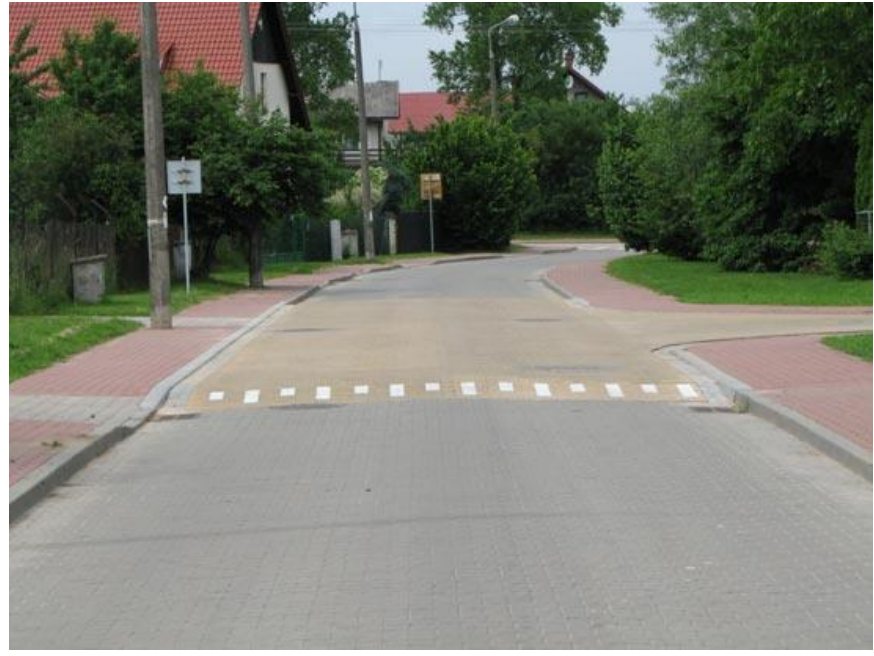

Rys. 4. Próg zwalniajacy typu poduszka źródło: [12 ]

- Próg wyspowy (przyjazny autobusom) (poduszka berlińska) - to próg zwalniający, najczęściej w postaci prostokątnej wypukłości na jezdni, o szerokości takiej, która umożliwia autobusowi przejazd nad progiem (bez wpływu na ruch autobusu), a samochodom osobowym nie, ze względu na ich węższy rozstaw kół (rys. 5)

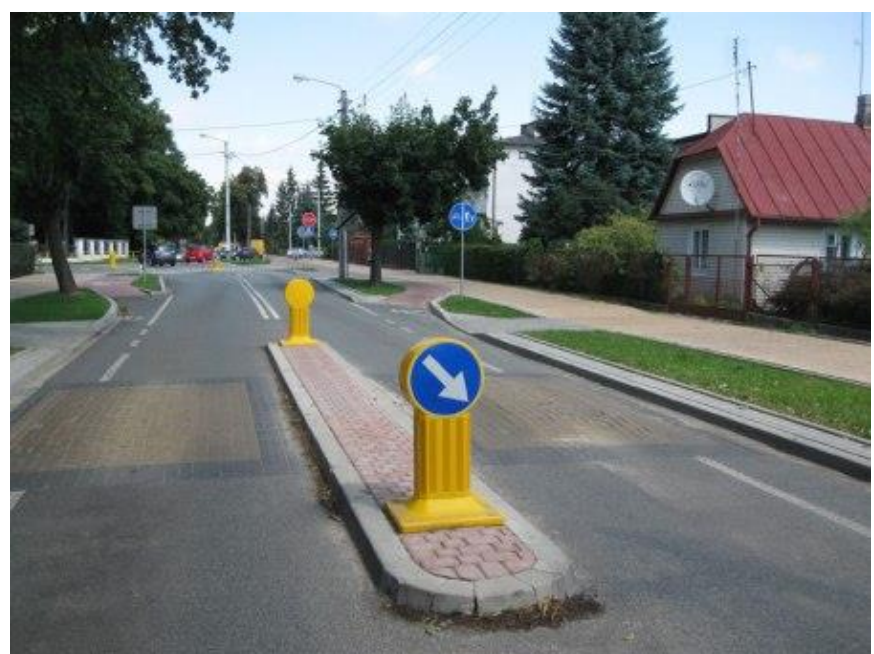

Rys. 5. Wyspowy próg spowalniajacy źródło: [11]

Wytyczne dotyczące progów zwalniających zostały szczegółowo opisane w załązniku nr 4 Rozporządzenia Ministra Infrastruktury z dnia 3 lipca 2003 r. w sprawie szczegółowych warunków technicznych dla znaków i sygnałów drogowych oraz urządzeń bezpieczeństwa ruchu drogowego i warunków ich umieszczania na drogach.

Zgodnie z założeniami załącznika nr 4 każdorazowo, oprócz przeanalizowania kwestii prawnych dotyczących możliwości zastosowania takiego rozwiązania w danym miejscu na drodze, decyzja o montażu progu zwalniającego wymaga również wzięcie pod uwage pozytywnych oraz negatywnych skutków takiego działania.

Do pozytywnych skutków zalicza się m. in.:

- miejscowe ograniczenie prędkości pojazdów kołowych, w szczególności w rejonach szkół, przedszkoli, placów zabaw i innych miejsc szczególnie uczęszczanych przed dzieci,

- niewielki koszt montażu takiego urządzenia i łatwość w jego montażu - zwłaszcza 
w przypadku progów listowych,

zmniejszenie natężenia ruchu drogowego, którego część, w przypadku montażu progów, może przenieść się na drogi równoległe, np. drogi o wyższej kategorii, oraz prawie całkowite wyeliminowanie ruchu tranzytowego $z$ drogi.

Do negatywnych skutków można zaliczyć m.in.:

- Zwiększenie hałasu i drgań w okolicy (punktowe wibracje) szczególnie uciążliwe dla posesji znajdujących się w bliskości zamontowanego progu. Im większy próg, tym kierowca silniej hamuje, a potem tym silniej przyspiesza. Jedno i drugie generuje wibracje i hałas. Kiedy ruch jest za duży samochody z hukiem przejeżdżaja przez progi. Huk, to już poważny problem. Jest on generowany w szczególności przez pojazdy wjeżdżające na progi zwalniające z pełną prędkością (np. ciężarówki, terenówki). Autobusy, które teoretycznie powinny przejeżdżać ponad progami a faktycznie zawadzają o nie, to kolejny problem - powoduja powstawanie silnych wstrząsów (punktowe wibracje) hałasu odczuwalnych w okolicznych zabudowaniach, co skutkuje nawet pękaniem ścian.

- Hamowanie przed i przyspieszanie za progami zwalniającymi zwiększa zużycie układu hamulcowego oraz paliwa i tym samym podwyższa emisje spalin.

- Konieczność zwalniania pojazdów uprzywilejowanych - pogotowia, straży pożarnej, policji podczas wykonywania interwencji.

- Negatywne oddziaływanie na konstrukcje drogi oraz na urzadzenia znajdujace się

w drodze - sieci wodociagowe i kanalizacyjne, sieci gazowe.

- Utrudnienia związane z prawidłowym odśnieżaniem jezdni i częste uszkodzenia progów listwowych przy odśnieżaniu.

- Utrudnienia w prawidłowym odwodnieniu drogi.

- Częste rozjeżdżanie poboczy i chodników przez kierowców wymijających progi.

Poniżej wyniki ankiety w której udział wzięło 522 kierowców w wieku od 16 do 60 lat przeprowadzonej przez Stowarzyszenie Integracji Stołecznej Komunikacji SISKOM Warszawa 2005 dotyczącej progów zwalniających

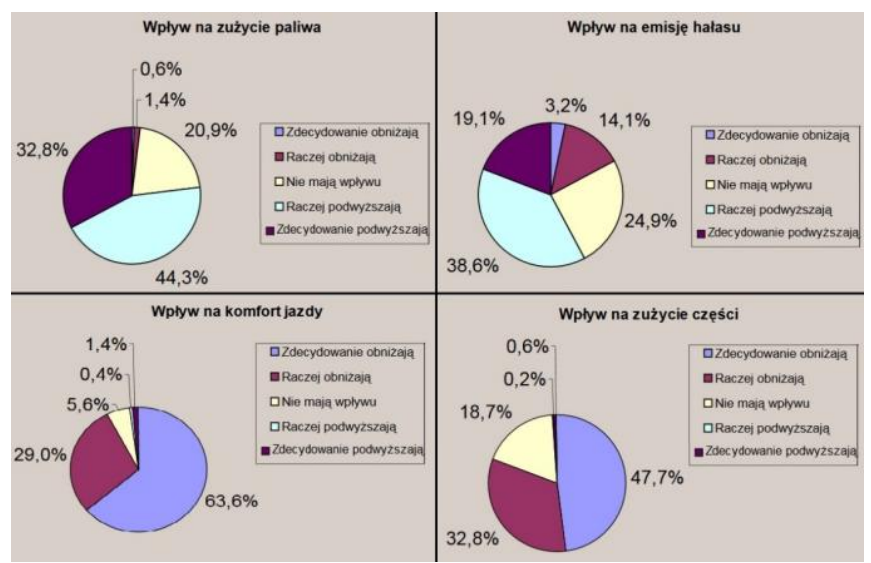

Rys. 6. Wyniki ankiety Stowarzyszenia Integracji Stołecznej Komunikacji

Żródło: [SISKOM]

Wyniki powyższej ankiety przeprowadzonej wśród kierowców wskazują na przekonania, że progi zwalniające podwyższają zużycie paliwa, emisję hałasu, obniżenie komfortu jazdy i przyspieszenie zużycia zawieszenia pojazdów.

Przy ocenie zasadności montażu progów zwalniających należy zawsze brać pod uwagę fakt, iż ze względu na moc obecnych po- jazdów próg pozwala zdyscyplinować nieprzepisowych kierowców tylko w odległości kilkudziesięciu metrów. Taka odległość jest wystarczająca aby przeciętnym pojazdem o mocy 100 KM osiagnąć prędkość ok. $50 \mathrm{~km} / \mathrm{h}$. Należy pamiętać, że progi przeważnie montuje się na drogach gminnych, które $z$ reguły są gęsto zabudowane budynkami, w związku z czym uciążliwość związana z hałasem, wibracją drganiami i spalinami może okazać się poważnym problemem. Biorac pod uwagę drgania, wibracje wywołane przez pojazd przejeżdżający przez próg zwalniający na co dzień mogą być praktycznie nieodczuwalne przez ludzi, natomiast ich skutki moga być bardzo poważne i dokuczliwe w przyszłości. Przykładem jest brytyjska miejscowość Derby, gdzie 146 progów tak się dało mieszkańcom we znaki (wielu zaczęło się skarżyć na bóle kręgosłupa), że wystapili o ich usunięcie mimo kosztów sięgających 460 tys. Funtów.

Na Zachodzie od progów się odchodzi. Zamiast nich stosuje się zwężenia dróg lub szykany, które trzeba omijać. Mają podobne zalety, wad znacznie mniej: nie generuja tyle wibracji i hałasu, nie narażaja zdrowia mieszkańców, kierowców i bezpieczeństwa pasażerów karetek pogotowia, nie utrudniają odśnieżania, nie niszczą aut, są bezpieczniejsze dla rowerzystów i motocyklistów.

Problem drgań przenoszonych do otoczenia przez komunikację samochodową funkcjonuje od początku jej istnienia. Z poczatku drgania te nie były brane pod uwagę, gdyż częstotliwość przejazdów oraz obciążenia były bardzo małe a poziom ich nie odbiegał od poziomu drgań od innych środków transportu, jak na przykład ciężarowych wozów konnych ze stalowymi obręczami kół, jeżdżących po brukowanych ulicach. W miarę postępu technicznego i rozwoju innych środków komunikacji, zaczęto zwracać uwagę już na etapie projektowania samochodowych na możliwość ograniczenia emisji hałasu i drgań pochodzących od tych pojazdów na środowisko. Zapobieganie procesowi rozprzestrzeniania się oddziaływań dynamicznych poprzez grunt na konstrukcje inżynierskie, emisji dźwięku lub drgań materiałowych wymaga zastosowania nowych rozwiąań zarówno materiałowych, jak i konstrukcyjnych, które spełniają warunki izolacji drganiowej pomiędzy źródłem emisji drgań a otoczeniem. Tu należałoby zastanowić się nad zastapieniem progów zwalniających innymi sposobami ograniczenia ruchu drogowego. W krajach wysoko rozwiniętych stosowane obecnie konstrukcje zezwalaja na znaczne ograniczenie emitowanego hałasu do otoczenia. Jako jedna z podstawowych metod ograniczenia poziomu hałasu i drgań przyjęto w tych krajach prawidłowo zaprojektowane i wykonane elementy dróg jezdnych zarówno samochodowych, jak i szynowych. Problem ten dotyczy nie tylko dróg samochodowych na których znajduja się progi zwalniające, ale także skrzyżowań jednopoziomowych dróg oraz skrzyżowań z drogami transportu szynowego. Ograniczenia prędkości w postaci progów zwalniających maja wpływ na płynność transportu drogowego, ale także wywołują oddziaływania dynamiczne (drgania), które są przenoszone do środowiska naturalnego człowieka.

\section{Progi zwalniające - pomagają, czy szkodzą?}

Przepisy mówia jasno, progi zwalniające „tylko w terenie zabudowanym". Przepisy sa jednak notorycznie łamane, jak np. w Nowej Iwicznej. Przejazd przez nią przypomina bieg przez płotki. Podobnie jest w większości podwarszawskich miejscowości i osiedli. Przygladając się uważniej miejscom, w których stawiane są progi zwalniające łatwo (znając przepisy) dojść do wniosku, że nie o bezpieczeństwo tu chodzi. Progi mają nie tyle chronić dzieci, ile odstraszać kierowców. Sprawiać, by wybierali inne ulice a te pocięte progami zwalniającymi zostawili w spokoju. To między innymi tłumaczy nagminne i rażące przekroczenie przepisowej wysokości progów, których wysokości w Nowej Iwicznej, Raszynie i Piasecznie docho- 
dzą nawet do 13-15 cm, czyli tyle ile wynosi prześwit samochodu osobowego. To oznacza dla niego ryzyko wielu uszkodzeń (miska olejowa, katalizator, czy tłumik) już po jednym uderzeniu a przy wielu przejazdach - przedwczesne zużycie amortyzatorów, hamulców, drażków i wahaczy.

Biorąc pod uwagę dodatkową emisję spalin nadmiar progów zwalniających przynosi skutek odwrotny od zamierzonego - zamiast chronić, szkodzą mieszkańcom. Zarządy dróg stawiają progi na każdą sugestię mieszkańców chcących ograniczyć ruch przy własnej posesji. Stąd tak wiele progów rażąco niezgodnych z normami i wciąż powstaja nowe - bo to najtańszy i najprostszy sposób uspokojenia ruchu, jednak w oderwaniu od przepisów obarczony zbyt licznymi wadami. Dlatego też należałoby zastanowić się nad stosowaniem innych rozwiązań uspokojenia ruchu, które byłyby mniej odczuwalne dla ludzi i środowiska, które nas otacza

i z którego na co dzień korzystamy.

\section{Bibliografia}

1. Ciesielski R., Kawecki J., Maciag E., Stypuła K., Ocena diagnostyczna skutków wpływów drgań na budynki i ludzi w budynkach, Inżynieria i Budownictwo nr 9/93

2. Engel Z., Ochrona środowiska przed drganiami i hałasem, Wydawnictwo Naukowe PWN, Warszawa $1993 \mathrm{r}$.

3. Rozporządzenie Ministra Infrastruktury z dnia 3 lipca 2003 r. w sprawie szczegółowych warunków technicznych dla znaków i sygnałów drogowych oraz urządzeń bezpieczeństwa ruchu drogowego i warunków ich umieszczania na drogach
4. Stypuła K., Nowoczesne wibroizolacje, Builder, str. 66-70, $10 / 2009$ r.

5. Sadowski J., Szudrowicz B., Inżynieria środowiska w kształtowaniu klimatu akustycznego środowiska i jego ochronie przed hałasem i drganiami. I Kongres Inżynierii Środowiska, Lublin 2002 r.

6. Targosz J., Ograniczenie oddziaływań dynamicznych od dróg kolejowych i samochodowych, monografia. Kraków, KRiDM AGH 2004 r.

7. http://www.siskom.waw.pl, 09.2005

8. http://www.yankodesign.com

9. http://www.badennova.com

10. Materiały zakładowe firmy Olsen

11. http://www.rowerowy.torun.pl

12. http://www.edroga.pl

\section{Autorzy :}

dr inż. Jarosław Bednarz - AGH Akademia Górniczo-Hutnicza im. Stanisława Staszica, Katedra Robotyki i Mechatroniki, al. Mickiewicza 30, 30-059 Kraków, e- mail: bednarz@agh.edu.pl dr hab. inż. Jan Targosz - AGH Akademia Górniczo-Hutnicza im. Stanisława Staszica, Katedra Robotyki i Mechatroniki, al. Mickiewicza 30, 30-059 Kraków, e-mail: jantargosz@interia.pl

mgr inż. Jacek Wiederek - doktorant Wydziału Transportu i Elektrotechniki Uniwersytetu Technologiczno-Humanistycznego im. Kazimierza Pułaskiego Radom, e-mail: wiederek.jacek@gmail.com 